\title{
The legal utility of performative practices: The case of Hong Kong
}

SHERWOOD DU

\section{Abstract}

The relationship between Hong Kong and the People's Republic of China is one of the most intriguing puzzles of the twenty-first century. However, while political aspects of Hong Kong's post-transfer era have been widely documented, there is little existing literature detailing the transition from legal theory perspectives. A precursory glance of Hong Kong showcases a cosmopolitan international city, famous for its abundance of oriental delicacies and alluring attractions complete with the signature glow of its illuminated skyline. This paper will present Hong Kong in a different light: a city captive to different perspectives of its legal philosophy foundations. On 10 October 2012, legislative councillor Raymond Wong Yuk-man strategically coughed in key passages of the 'Oath of Legislative Councillors', effectively omitting all references to the People's Republic of China as prescribed by law. To examine how this was made possible, four main terms will be introduced: rule of law, rule by law, performative and performance. The central theme of this paper explores the utility of performatives as a mechanism to moderate normative discourses and measures their functional value against its effects in the social sphere. The difference between performatives and performances will be highlighted to demonstrate limitations to the coercive elements of performative practices intended by the oath's framers. The second part of this paper undertakes to explain the significance of the subversion of the swearing-in ceremony and its repercussions. A key observation is that the effectiveness of written law is limited by the spirit of conscience, the last refuge of Hong Kongese cultural identity. 


\section{Introduction}

Tuesday 1 July 1997 marked a new chapter in Hong Kong. Its 156-year-old status as a British colony was ended by the transfer of sovereignty to the People's Republic of China (PRC). ${ }^{1}$ Despite meticulous planning by the British and Chinese governments to ensure a smooth transition, ${ }^{2}$ Hong Kong's contemporary landscape is marred by controversies revolving around PRC's encroachment upon Hong Kong's unique independence, known as the 'One Country: Two Systems' principle. ${ }^{3}$ This article focuses on the Hong Kong Legislative Council oath of office as a mirror reflecting the frayed relationship between the grassroots Hong Kongese and PRC authorities. ${ }^{4}$ First, the conceptual differences between Hong Kong and the PRC of what law is will be provided as an account of how the performative oath was intended to function by its framers. Second, it is advanced that the oath was designed to ensure Hong Kong's elected representatives recognise PRC rule as legitimate by way of performative practices. ${ }^{5}$ Although performative practices aim to entrench hegemonic interests in reinventing Hong Kong's social identity, performatives are susceptible to be undermined by their very own nature of performance.

\section{Context}

\section{Concepts of law}

The Hong Kong-PRC context provides an insight into the oath's requirement of swearing 'allegiance' to the PRC and reasons as to why it is unpalatable to grassroots Hong Kongese. ${ }^{6}$ The PRC is widely regarded as anti-rule of law with the potential to affect Hong Kong's rule of law culture in the post-transfer era. Although it is noted that Hong Kong's rule of law may be criticised as a product

1 Fareed Zakaria, 'The Rise of Illiberal Democracy' (1997) 76(6) Foreign Affairs 22, 29.

2 Yash Ghai, Hong Kong's New Constitutional Order: The Resumption of Chinese Sovereignty and the Basic Law (Hong Kong University Press, 2nd ed., 1997) 35.

3 Ibid., 140.

4 It reads:

I swear that, being a member of the Legislative Council of the Hong Kong Special Administrative Region of the People's Republic of China, I will uphold the Basic Law of the Hong Kong Special Administrative Region of the People's Republic of China, bear allegiance to the Hong Kong Special Administrative Region of the People's Republic of China and serve the Hong Kong Special Administrative Region conscientiously, dutifully, in full accordance with the law, honestly and with integrity.

Oaths and Declarations Ordinance (Hong Kong) cap 11, s 19 ('Oath of Legislative Councillors') (emphasis added); 'Hong Kongese' and 'Hongkonger' are new terms to describe the Hong Kong populace. See Oxford English Dictionary (OED), New Words List (March 2014), public.oed.com/the-oed-today/recent-updates-to-the-oed/ march-2014-update/new-words-list-march-2014/.

5 Judith Butler, 'Performative Acts and Gender Constitution: An Essay in Phenomenology and Feminist Theory' 40(4) Theatre Journal 519, 520.

6 Oath of Legislative Councillors, s 19. 
of British colonialism, ${ }^{7}$ this article distances itself from the political sphere to isolate the debate in the frame of theoretical differences between Hong KongPRC philosophies of law. ${ }^{8}$ In modern society, for any authority to be accepted as legitimate, its source of power must stem from law:

... the significance of law for social theory is affirmed in the most unambiguous terms. Law is the foundation of central structures of social life; a set of processes and procedures on which society's very integrity depends. ${ }^{9}$

From the 1970s, incremental shifts towards a rights discourse was introduced to Hong Kong so that its populace was accustomed to expect governments to act with procedural fairness and provide access to avenues of legal redress; contrasted with the PRC portrayed as without such systematic legal safeguards. ${ }^{10}$ The example of the Tiananmen Square Massacre animates fundamental differences between Hong Kong and PRC concepts of law by how protestors were handled in the respective territories: 'Hong Kong - city of law - and Beijing - city of tanks' ${ }^{11}$ The massacre encapsulates the notion of Hong Kong grounded in the rule of law, and PRC as rule by law. While rule of law is an institutional guarantee against the abuse of power by government, rule by law is merely when the law is used as a means to an end for purely governmental interests. ${ }^{12}$ Under a rule of law system, a government's legitimacy in the eyes of its populace is founded from the concept self-determination, 'citizens should always be able to understand themselves also as authors of the law to which they are subject as addressees' ${ }^{13}$ In contrast, rule by law was dramatically demonstrated when PRC used the caricature of law as a pretence to preserve its own power by violently suppressing civilian dissident voices. Rule by law also explains the rationale behind the irony of the ruling PRC Communist Party reaping the fruits

7 Carol Jones, 'Politics Postponed: Law as a Substitute for Politics in Hong Kong and China' in Kanishka Jayasuriya (ed) Law, Capitalism and Power in Asia: The Rule of Law and Legal Institutions (Routledge, 2006) 38,52 .

8 Michael Wesley provides an illustrative account of Hong Kong-PRC political relations:

It used to be the case that mainlanders were the poor cousins. The trickle of them that used to come into Hong Kong would sort of wander around, sort of with their mouths open, looking at the opulence and the beautiful buildings and everything, and the Hongkongers were the rich ones who would look down on these sorts of country bumpkins. The shoe is on the other foot now of course in terms of wealth, where the mainlanders that generally come to Hong Kong are fabulously wealthy, much wealthier than most Hongkongers, and I think they probably quite enjoy acting in ways that they know irritate the locals, just to, you know, sort of flaunt their new found wealth, and of course, the fact that now Beijing really has this former colony under its control.

ABC Radio National, 'Hong Kong Residents Lash Out Against “Uncivilised" Chinese Tourists,' PM, 13 May 2014 (Michael Wesley), www.abc.net.au/pm/content/2014/s4003860.htm.

9 Roger Cotterrell, Law, Culture and Society: Legal Ideas in the Mirror of Social Theory (Ashgate, 2006) 26 (citations omitted).

10 Jones, above $\mathrm{n} 7,53$

11 Ibid., 52. After the 4 June incident, over one million people protested peacefully in Hong Kong.

12 Brian Z. Tamanaha, On the Rule of Law: History, Politics, Theory (Cambridge University Press, 2004) 3.

13 Jürgen Habermas, Between Facts and Norms: Contributions to a Discourse Theory of Law and Democracy (William Rehg trans, MIT Press, 2nd ed., 1996) 449. 
of capitalism. Because rule by law categorises 'law as a technology devoid of values', ${ }^{14}$ it permits the facilitation of capitalism as a utility that is sanctioned by the state to further its own goals of state-building. Ignoring the causal link between an individual's economic power and political privilege, ${ }^{15}$ the ethos of rule by law severs the normative underpinnings as to why law should be obeyed; it 'collapses the political, the social and cultural into the legal: the legal is then submerged into the economic ${ }^{\prime}{ }^{16}$ Legitimacy under rule by law is not obtained by appealing to social values, but by the sole reason of the existence of law as a command, where its subjects are required to adopt a performative attitude in that law is complied with 'out of respect for the law', ${ }^{17}$ enforced by state sanction.

Before the transfer of sovereignty, to Hongkongers the rule of law was cherished as a differentiating characteristic from the PRC as an important normative identity that transcends criticisms of residual colonialism. It was emblematic of the freedoms to criticise authority and guaranteed civil liberties against abuse of power by government, a luxury not afforded in the PRC. Jones describes this phenomenon in layperson terms as a differencing factor between Hong Kong and PRC ideas about law:

Talking about law has become a means of keeping this 'Other' at bay, of differentiating oneself as 'Hong Kong Chinese,' of mapping out the future in the hope, one suspects, of exercising some control over it. ${ }^{18}$

From Jones' account, we can infer that Hong Kong's ideology of law has a potent flavour of self-determination and, hence, subscribes to the rule of law. However, in the post-transfer era, rule of law is threatened by irreconcilable differences between Hong Kong and PRC philosophies of law. Before delving into techniques PRC deploys to substitute rule of law with rule by law, it is useful to turn to Hong Kong's contemporary governance framework to explain the challenges to Hong Kong's rule of law ideology.

\section{Administrative governance insights: Hegemony hiding in plain sight}

When PRC resumed sovereign control over Hong Kong, the PRC promised a 'One Country: Two Systems' arrangement. This slogan purported to allow Hong Kong the same degree of autonomy as before 1 July 1997:

14 Jones, above $\mathrm{n} 7,54$

15 Karl Marx and Friedrich Engels, 'The Communist Manifesto' (1998) 34 Socialist Register 240, 245.

16 Jones, above $\mathrm{n} 7,55$

17 J.L. Austin, How to Do Things with Words (Oxford University Press, 1962) 4-5; Habermas, above n 13, 448.

18 Jones, above n 7, 53 (emphasis added). 
The socialist system and policies shall not be practised in the Hong Kong Special Administrative Region, and the previous capitalist system and way of life shall remain unchanged for 50 years. ${ }^{19}$

While the populist mantra may be heralded as a success because of its associated promise to not interfere with Hong Kong's capitalist system,,$^{20}$ the same cannot be said with its promise to not interfere with Hong Kong's 'way of life' - its selfdetermination culture under the rule of law. ${ }^{21}$ At this point it is logical to ask, why would the PRC allow capitalism but not the territory's status quo social conditions? The answer lies in the PRC's legal philosophy: rule by law. The way PRC authorities selectively operate article 5 is linked to the previous discussion of law as a utility without values under rule by law. ${ }^{22}$ Prima facie, allowing capitalism to exist with its socialist antithesis should be analogous with allowing the theories of rule of law and rule by law to coexist. However, the delicate difference between the two analogised subjects is that while the former explains the operation of social theory under peripheral concepts of the use of law, the latter concerns the core notions of what law is. Thus, as the question of what law is must be answered in absolute terms ${ }^{23}$ then it follows that the appeal of the rule of law as effecting institutional safeguards is irreconcilable with rule by law as blunt commands. As the PRC occupies the role of the hegemonic power in Hong Kong-PRC relations, it is improbable for the PRC to not attempt to alter the core of the Hong Kong legal system in transcribing its rule by law mentality into social reality, ${ }^{24}$ as evidenced by the recent publication of a PRC White Paper which purports to reduce Hong Kong's objective political autonomy into merely a subjective feature to be enjoyed only by 'authorization' of the PRC. ${ }^{25}$ In addition, interference in Hong Kong's affairs is enshrined in Hong Kong's judicial system where the Court of Final Appeal is required to

19 Basic Law of the Hong Kong Special Administrative Region of the People's Republic of China, art 5 ('HKSAR Basic Law') (emphasis added).

20 Christine Loh, 'Government and Business Alliance: Hong Kong's Functional Constituencies' in Christine Loh and Civic Exchange (eds), Functional Constituencies: A Unique Feature of the Hong Kong Legislative Council (Hong Kong University Press, 2006) 19.

21 HKSAR Basic Law, art 5.

22 Ibid.

23 Tamanaha, above n 12, 3.

24 Joseph Raz provides the proposition of law as a political institution:

The law is, however, not merely a set of guides for court decisions. It is a political institution of great importance to the working of societies and to their members. From this point of view a British person cannot say 'Polish law is my law' just because it will be followed by British courts when their conflictof-law rules direct them to do so. The distinction between standards that the courts have to apply and those that are the law of the land is vital to our ability to identify the law as the political institution it is. Joseph Raz, 'Incorporation by Law' (2004) 10(1) Legal Theory 1, 15.

25 Information Office of the State Council of the People's Republic of China, 'The Practice of the "One Country Two Systems" Policy in the Hong Kong Special Administrative Region' (White Paper, 10 June 2014) Part V, www.china.org.cn/government/whitepaper/node_7207387.htm. 
seek interpretation from the PRC for Hong Kong-PRC issues. ${ }^{26}$ Interference is also rooted in the executive branch. ${ }^{27}$ First, the Chief Executive (CE) serves as the principal of the government and reserves the right to appoint officials to the Executive Council. ${ }^{28}$ Second, the CE is empowered to select and remove the Secretaries and Deputy Secretaries across all government bureaus. ${ }^{29}$ Third, the $\mathrm{CE}$ is empowered to select and remove judges throughout the court hierarchy system. ${ }^{30}$ The critical aspect of this arrangement is that the position of CE itself is appointed by the PRC following ballot results from a PRC-controlled 1,200-person nomination committee whose composition represents 0.02 per cent of Hong Kong residents. ${ }^{31}$ The aforementioned public officers are selected by the CE - who are only 'nominated' because the CE requires the express approval of the PRC for such candidates to be officially appointed. ${ }^{32}$

In contrast, the legislative branch goes through more comprehensive elections than the CE selection process. ${ }^{33}$ It is perceived at the grassroots level as a more representative vehicle of Hong Kongese interests than the CE, judicial and executive branches. In theoretical terms, the Legislative Council reflects the populace's perceptions of having institutional safeguards against the command and control elements of Hong Kong's governance system. However, upon successful election, prospective legislative councillors are faced with a dilemma: how to resolve the conflict between rule of law and rule by law in partaking in the oath? How can legislative councillors serve the interests of their constituencies without the freedom to oppose government legislation against PRC interests in

26 HKSAR Basic Law, art 158; Anthony Mason, 'The Hong Kong Court of Final Appeal' [2001] 2(1) Melbourne Journal of International Law 216, 219. The PRC White Paper has also attracted the ire of the Hong Kong legal community which denounced it as threatening the territory's judicial independence and undermining the rule of law: Edward Ngai and Chester Yung, 'Hong Kong Lawyers March for Judicial Independence,' The Wall Street Journal (online), 27 June 2014, online.wsj.com/articles/hong-kong-lawyers-march-for-judicialindependence-1403873329.

27 HKSAR Basic Law, c 4 (Political Structure).

28 Ibid., arts 43, 55. For an overview of the Executive Council's (ExCo) functions, see Paul Morris, Flora Kan and Esther Morris, 'Education, Civic Participation and Identity: Continuity and Change in Hong Kong' (2000)

30(2) Cambridge Journal of Education 243, 251.

29 HKSAR Basic Law, art 48(5).

30 Ibid., art 48(6).

31 Ibid., art 45; Annex I (Amendment to Annex I to the Basic Law of the Hong Kong Special Administrative Region of the People's Republic of China Concerning the Method for the Selection of the Chief Executive of the Hong Kong Special Administrative Region, approved at the Sixteenth Session of the Standing Committee of the Eleventh National People's Congress, 28 August 2010, Instrument 2); Te-Ping Chen, 'Meet Hong Kong's Voters - All 1,200 of Them,' The Wall Street Journal (online), 19 March 2012, blogs.wsj.com/ chinarealtime/2012/03/19/meet-hong-kong \%E2\%80\%99s-voters-all-1200-of-them/.

32 HKSAR Basic Law, art 48(5)-(6).

33 Ibid., art 68. For a comprehensive analysis of the Legislative Council's electoral process and commentary on Hong Kong's direct and functional constituency elections, see Gladys Li and Nigel Kat, 'The Legal Status of Functional Constituencies' in Christine Loh and Civic Exchange (eds), Functional Constituencies: A Unique Feature of the Hong Kong Legislative Council (Hong Kong University Press, 2006) 143, 143-154. 
swearing 'allegiance' to the PRC ${ }^{34}$ The next part of this analysis will evaluate the framer's purpose behind the oath, contending that its performative nature backfires on its creators.

\section{Performatives: A double-edged sword}

\section{Origins}

J.L. Austin is credited to have coined the term performative. ${ }^{35}$ Performatives arise in speech acts when the issuing of the utterance is the performing of an action', ${ }^{36}$ such that saying a performative phrase does not mean to describe the operative effect of the utterance other than 'to do it'. ${ }^{37}$ For example, at a wedding when the words 'I do (take this woman to be my lawful wedded wife)' are uttered, ${ }^{38}$ it is commonly accepted as completing the requirements for a marriage ceremony. Austin contends that when people say 'I do', it is not really the end of the meaning of the phrase. Instead, the speech of ' $\mathrm{I}$ do', needs to be qualified by actions or further phrases to give meaning to the words: "when I say, before the registrar or altar, \&c., "I do", I am not reporting on a marriage: I am indulging in it'. ${ }^{39}$ To clarify, saying 'I marry you' does not automatically fulfil the act described by the utterance as a reality. The phrase must be qualified by complementary actions:

... It is very commonly necessary that either the speaker himself or other persons should also perform certain other actions, whether 'physical' or 'mental' actions or even acts of uttering further words. ${ }^{40}$

Thus, performative utterances only describe commitments to spoken words which require further actions to fulfil its contents. The next section will outline the usages of performatives in circumstances where performance is mandatory.

\section{Performative function}

The effects of a performative vary according to its intended context. While basic performatives such as 'thanking' and 'notifying' are informal communications, when people formally say 'I do' to a marriage, they are accepting the institutional framework that qualifies the meaning behind the phrase. ${ }^{41}$ Similarly, swearing

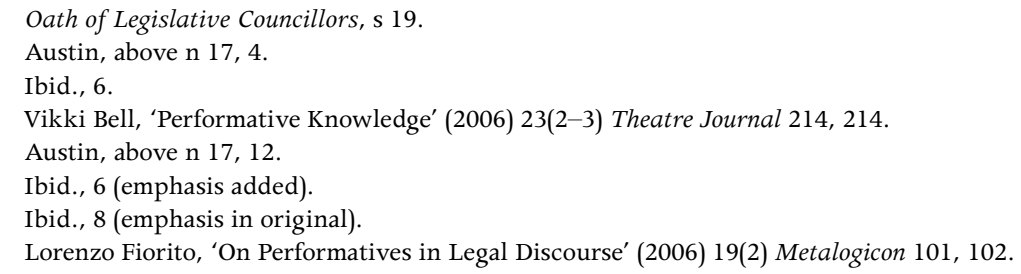


allegiance to a particular institution requires a deeper internal acknowledgement and explicit acceptance of the contents of what is being sworn to. ${ }^{42}$ Turning back to the oath, it is worth revisiting that the 'PRC' is scripted no less than three times, qualified by the phrase, 'in full accordance with the law ...'. ${ }^{43}$ It is advanced that the oath is designed to inhibit a subconscious link to a partaker's mind such that the terms 'in full accordance with the law' is associating the PRC's rule by law as the principle governing the Legislative Council and, in turn, the Hong Kongese populace as their electors. ${ }^{44}$ On an aesthetic level, the televised nature of the swearing-in ceremony augments the performative's influencing power as it permeates the public sphere. ${ }^{45}$ The public dissemination of the performative ceremony in Hong Kong's unicameral legislative chamber purports to influence a viewer's mind of the oath's normative authenticity. ${ }^{46}$ This is further entrenched by the oath being repeatedly cited by all legislative councillors after every election. The performative via repetition ${ }^{47}$ seeks to reconfigure the roots of Hong Kong's rule of law ethos by ritualising the oath to create a precedent atmosphere, giving the illusion of the oath as an already established social norm. In turn, it is expected by PRC authorities that when the oath is performed, its function seeks to reinvent social reality:

... the appearance of substance is precisely that, a constructed identity, a performative accomplishment which the mundane social audience, including the actors themselves, come to believe and to perform in the mode of belief. ${ }^{48}$

Hence, when legislators swear allegiance, they do so to an alternative social context that seeks to replace the status quo. To emphasise, when prospective legislative councillors swear allegiance to the PRC, they are contributing to the PRC project of rule by law eclipsing rule of law in Hong Kong's social discourse. It also follows that the authority behind the performative to bind legislators to act out the oath is nothing other than the enforcement mechanism of law itself - a key indicia of the nature of rule by law. ${ }^{49}$ As rule by law is imposed by the

\footnotetext{
42 Ibid.

43 Oath of Legislative Councillors, s 19 (citations omitted).

44 Raz, above n 24, 15.

45 Legislative Council of the Hong Kong Special Administrative Region of the People's Republic of China, Legislative Council Secretariat (Public Information Division) (2014) LegCo, www.legco.gov.hk/general/english/ sec/corg_ser/pi.htm. While this paper focuses on the Legislative Council oath, similar ceremonial performatives are scripted in the office of Chief Executive, executive and judicial branches, reflecting a concerted effort by PRC authorities to consolidate social control over the territory: Oaths and Declarations Ordinance (Hong Kong) cap 11, ss 16-22; HKSAR Basic Law, art 104.

46 The architectural themes of the Legislative Council Complex are designed to be emblematic of the 'transparent and dignified image of the Legislature'. See Legislative Council of the Hong Kong Special Administrative Region of the People's Republic of China, Architectural Design (2014) LegCo, www.legco.gov. hk/general/english/visiting/complex_tamar.html.

47 Butler, above n 5, 526 .

48 Ibid. (citations omitted)

49 Rachel Sanders, 'Justice at Trial: Dramatic Ironies of the Postracial State' (2013) 9(1) Law, Culture and the Humanities 133, 148.
} 
performative oath, the illusion of rule of law renders its partakers complicit in accepting attempted alterations to the status quo. This finding has not gone unnoticed and some legislators use active and passive tactics to undermine the performative oath.

\section{Active resistance}

In 2004, a legislator sought judicial review to challenge the oath by asking the court whether the oath could be personalised according to personal values:

I, Leung Kwok-Hung, solemnly, sincerely, and truly declare and affirm that I swear by the people of China and the residents of Hong Kong, as well as the principles of democracy, justice, human rights and freedom that, being a member ... ${ }^{50}$

In determination, while the presiding judge appreciated the amendment's sentiments, it was found to be not in line with the positivistic colour of the oath:

It constitutes a solemn declaration, a form of promise, which binds the maker to a particular code of conduct ... no matter how laudable the sentiments expressed in them - are not prescribed by the Ordinance. ${ }^{51}$

The performative oath is designed to bind legislators to fulfil it at the penalty of expulsion from office. ${ }^{52}$ Similar to Butler's analysis of performatives rendering 'social laws explicit', the oath aims to reinvent social reality by enforcing its strict performance according to its framer's prescription. ${ }^{53}$ Furthermore, although the case judgment concurred that the oath was not inconsistent with article 32 of the Basic Law - the right to freedom of conscience ${ }^{54}-$ it is respectfully concluded that the case reasoning was erroneous as it did not take into account the use of performatives to promote singular legal philosophies in concluding that, 'It is no form of indoctrination nor can it be described as any form of attempt to influence the applicant's conscious or subconscious mind' ${ }^{55}$ Without repeating the previous discussion on the mechanics of performativity in Hong Kong's social context and theories of legal philosophy, it can be seen that performatives reinforce hegemonic interests by forcing obedience and disallowing the dissenting values of rule of law proponents. ${ }^{56}$

50 The rest of the modified version of the oath is unamended. See Oath of Legislative Councillors, s 19 (citations omitted); Leung Kwok-Hung v Legislative Council Secretariat [2004] HKCFI 883 (6 October 2004), [7] (emphasis in original).

51 Leung Kwok-Hung v Legislative Council Secretariat [2004] HKCFI 883 (6 October 2004), [5]-[8] (citations omitted).

52 HKSAR Basic Law, arts 79(7), 104.

53 Leung Kwok-Hung v Legislative Council Secretariat [2004] HKCFI 883 (6 October 2004), [37].

54 HKSAR Basic Law, art 32.

55 Leung Kwok-Hung v Legislative Council Secretariat [2004] HKCFI 883 (6 October 2004), [38].

56 Sanders, above n 49, 133. 


\section{Passive resistance}

The weakness in performative acts is that since they are identified by physical actions and utterances, they cannot be considered true or false but only 'felicitous or infelicitous' ${ }^{57}$ While the oath encourages active acceptance of PRC's interference in Hong Kong, the fatal flaw in this strategy is that although physical actions can be controlled by the law, subversive intentions cannot be neutralised if actions are performed insincerely. ${ }^{58}$ For example, if a misbehaving son says to his father, 'I promise to do anything you ask me to do', ${ }^{59}$ the father based on intuition would not interpret the son literally. In 2012, veteran legislator Wong Yuk-man strategically coughed in key passages of the oath, effectively omitting all references to 'PRC'. Although Wong subsequently volunteered to retake the oath amidst criticism of it not being performed 'in full accordance with the law ${ }^{\prime}{ }^{60}$ his passive resistance is demonstrative of a performative's weakness. Consequently, at Wong's second swearing-in ceremony, Wong changed his tone throughout the oath in highly vocalising 'Hong Kong' and 'People' while whispering 'PRC' ${ }^{61}$ Even when another legislator challenged the legal validity of the second oath, the President of the Legislative Council ruled that it was in compliance with the Basic Law. ${ }^{62}$ So whether a performative succeeds in its designed intention is dependent on how it is performed by its recipients who performs them and how it is received. ${ }^{63}$ In essence, 'the outward utterance is a description, true or false, of the occurrence of the inward performance' ${ }^{64}$ Hence, one can always claim to be passively undermining the performative oath's intended function if the performed action is not actually believed.

\section{Conclusion}

At the macro level, performatives can be harnessed to bind performers to particular forms of conduct to facilitate the reconstruction of social narratives in the public domain. At the micro level, performatives act as a scan to identify

\footnotetext{
57 Fiorito, above n 41, 101.

58 Kent Bach and Robert M Harnish, 'How Performatives Really Work: A Reply to Searle' (1992) 15(1) Linguistics and Philosophy 93, 97.

59 Ibid.

60 Tanny Chung (channel alias)，2012 立法會議員宣誓就任: 梁國雄〉陳偉業〉黃毓民〉毛孟靜〉陳志全 (9 November 2012) YouTube (4.55), www.youtube.com/watch?v=dL-HqXZweMY\&feature =youtu.be \&t=4m55s; Tony Cheung, 'Wong Yuk-man Vows More Surprises When He Retakes Oath of Office,' South China Morning Post (online), 13 October 2012, www.scmp.com/news/hong-kong/article/1059825/wong-yuk-man-vows-moresurprises-when-he-retakes-oath-office; Oath of Legislative Councillors, s 19.

61 Yukman2010 (channel alias), 黃毓民第二次莊嚴宣誓, 效忠和熱誠服務香港, 堅決打倒港共政權 (16 October 2012) YouTube www.youtube.com/watch?v=E79ulOGx7as.

62 Ibid.; Tony Cheung, 'Wong Yuk-man Retakes Oath of Office to Legco,' South China Morning Post (online), 18 October 2012, www.scmp.com/news/hong.../wong-yuk-man-retakes-oath-office-legco.

63 Bach and Harnish, above n 58, 97.

64 Austin, above n 17, 9 (emphasis in original).
} 
those who accept or resist them. In turn, the oath's requirements act as hurdles against its detractors while rewarding its supporters with public office. Its purpose appears to succeed from bottom-up and top-down perspectives. However, its utility is dependent on how it is performed and received by its framers. Actioned subversively, its intended function fails when it is performed for superficial display. Performative weapons deployed for social engineering purposes can be undermined by their transactional nature: since performance is mandatory, acceptance of completed performances by their framers is also compulsory as legislators are inducted into office. Legislators can continue to advocate fearlessly for Hong Kongese interests while murmuring the scripted oath because the only validator of their consciences is who they see in the mirror.

\section{Acknowledgements}

I am indebted to Joshua Neoh and Heather Roberts, Lecturers in Law, for their conceptual guidance underpinning this article. All errors are my own. This paper was originally written in part fulfilment of LAWS2280: Law and the Humanities, first semester, 2014, The Australian National University. Paper presented on 18 September 2014 as a spoken presentation at the Australasian Conference of Undergraduate Research (ACUR). Thank you to Dr Dierdre Pearce for convening the oral presentation skills workshop in preparation for ACUR.

\section{Bibliography}

\section{A. Articles/Books/Reports}

Austin, John L., How to Do Things with Words (Oxford University Press, 1962).

Bach, Kent, and Robert M. Harnish, 'How Performatives Really Work: A Reply to Searle' (1992) 15(1) Linguistics and Philosophy 93.

Bell, Vikki, 'Performative Knowledge' (2006) 23(2-3) Theatre Journal 214.

Butler, Judith, 'Performative Acts and Gender Constitution: An Essay in Phenomenology and Feminist Theory' 40(4) Theatre Journal 519.

Cotterrell, Roger, Law, Culture and Society: Legal Ideas in the Mirror of Social Theory (Ashgate, 2006).

Fiorito, Lorenzo, 'On Performatives in Legal Discourse' (2006) 19(2) Metalogicon 101. 
Ghai, Yash, Hong Kong's New Constitutional Order: The Resumption of Chinese Sovereignty and the Basic Law (Hong Kong University Press, 2nd ed., 1997).

Habermas, Jürgen, Between Facts and Norms: Contributions to a Discourse Theory of Law and Democracy (William Rehg trans, MIT Press, 2nd ed., 1996).

Jones, Carol, 'Politics Postponed: Law as a Substitute for Politics in Hong Kong and China' in Kanishka Jayasuriya (ed) Law, Capitalism and Power in Asia: The Rule of Law and Legal Institutions (Routledge, 2006) 38.

Li, Gladys and Nigel Kat, 'The Legal Status of Functional Constituencies' in Christine Loh and Civic Exchange (eds), Functional Constituencies: A Unique Feature of the Hong Kong Legislative Council (Hong Kong University Press, 2006) 143.

Loh, Christine, 'Government and Business Alliance: Hong Kong's Functional Constituencies' in Christine Loh and Civic Exchange (eds), Functional Constituencies: A Unique Feature of the Hong Kong Legislative Council (Hong Kong University Press, 2006) 19.

Marx, Karl and Friedrich Engels, 'The Communist Manifesto' (1998) 34 Socialist Register 240.

Mason, Anthony, 'The Hong Kong Court of Final Appeal' [2001] 2(1) Melbourne Journal of International Law 216.

Morris, Paul, Flora Kan and Esther Morris, 'Education, Civic Participation and Identity: Continuity and Change in Hong Kong' (2000) 30(2) Cambridge Journal of Education 243

Raz, Joseph, 'Incorporation by Law' (2004) 10(1) Legal Theory 1.

Sanders, Rachel, 'Justice at Trial: Dramatic Ironies of the Postracial State' (2013) 9(1) Law, Culture and the Humanities 133.

Tamanaha, Brian Z., On the Rule of Law: History, Politics, Theory (Cambridge University Press, 2004).

Zakaria, Fareed, 'The Rise of Illiberal Democracy' (1997) 76(6) Foreign Affairs 22.

\section{B. Case}

Leung Kwok-Hung v Legislative Council Secretariat [2004] HKCFI 883 (6 October 2004), www.hklii.hk/eng/hk/cases/hkcfi/2004/883.html. 


\section{Legislation}

Basic Law of the Hong Kong Special Administrative Region of the People's Republic of China, art 5 ('HKSAR Basic Law').

Oaths and Declarations Ordinance (Hong Kong) cap 11 ('Oath of Legislative Councillors').

\section{Other}

ABC Radio National, 'Hong Kong Residents Lash Out Against "Uncivilised" Chinese Tourists,' PM, 13 May 2014 (Michael Wesley). www.abc.net.au/pm/ content/2014/s4003860.htm.

Chen, Te-Ping, 'Meet Hong Kong's Voters - All 1,200 of Them,' The Wall Street Journal (online), 19 March 2012, blogs.wsj.com/chinarealtime/2012/03/19/ meet-hong-kong \%E2\%80\% 99s-voters-all-1200-of-them/.

Cheung, Tony, 'Wong Yuk-man Vows More Surprises When He Retakes Oath of Office,' South China Morning Post (online), 13 October 2012, www.scmp.com/ news/hong-kong/article/1059825/wong-yuk-man-vows-more-surpriseswhen-he-retakes-oath-office.

Cheung, Tony, 'Wong Yuk-man Retakes Oath of Office to Legco,' South China Morning Post (online), 18 October 2012, www.scmp.com/news/hong.../ wong-yuk-man-retakes-oath-office-legco.

Chung, Tanny (channel alias), 2012 立法會議員宣誓就任: 梁國雄〉陳偉業〉黃 毓民〉毛孟靜〉陳志全 (9 November 2012) YouTube (4.55), www.youtube. $\mathrm{com} /$ watch $? \mathrm{v}=\mathrm{dL}-\mathrm{HqXZweMY} \&$ feature $=$ youtu. $\mathrm{be} \& \mathrm{t}=4 \mathrm{~m} 55 \mathrm{~s}$.

Information Office of the State Council of the People's Republic of China 'The Practice of the "One Country Two Systems" Policy in the Hong Kong Special Administrative Region' (White Paper, 10 June 2014), www.china. org.cn/government/whitepaper/node_7207387.htm.

Legislative Council of the Hong Kong Special Administrative Region of the People's Republic of China, Architectural Design (2014) LegCo, www.legco. gov.hk/general/english/visiting/complex_tamar.html.

Legislative Council of the Hong Kong Special Administrative Region of the People's Republic of China, Legislative Council Secretariat (Public Information Division) (2014) LegCo, www.legco.gov.hk/general/english/sec/corg_ser/ pi.htm. 
Ngai, Edward and Chester Yung, 'Hong Kong Lawyers March for Judicial Independence,' The Wall Street Journal (online), 27 June 2014, .

Oxford English Dictionary (OED), New Words List (March 2014), public.oed. $\mathrm{com} /$ the-oed-today/recent-updates-to-the-oed/march-2014-update/newwords-list-march-2014/.

Yukman2010 (channel alias)，黃毓民第二次莊嚴宣誓，效忠和熱誠服務香 港，堅決打倒港共政權 (16 October 2012) YouTube, www.youtube.com/ watch?v=E79ulOGx7as. 
This text is taken from The ANU Undergraduate Research Journal, Volume Six, 2014, edited by Jonathon Zapasnik and Alexandra Hogan, published 2015 by ANU eView, The Australian National University, Canberra, Australia. 